\title{
State of pathophysiology in undergraduate nursing education: A systematic review
}

\author{
Renee Colsch; Suzanne Lehman, Katherine Tolcser \\ Department of Nursing, Saint Catherine University, United States
}

Received: October 8, 2020

Accepted: November 3, 2020

Online Published: November 9, 2020

DOI: $10.5430 /$ jnep.v11n3p11

URL: https://doi.org/10.5430/jnep.v11n3p11

\begin{abstract}
Background: Nurses who understand pathophysiology can provide higher quality patient care. Various pedagogical strategies make it unclear which practice meets the challenges of teaching pathophysiology. The aim of this systematic review was to synthesize research in the last ten years to report the current state of pedagogical strategies related to teaching pathophysiology concepts in undergraduate nursing.

Methods: A systematic review of mixed, quantitative, and qualitative literature guided by the Preferred Reporting Items for Systematic Reviews and Meta-Analyses guidelines was conducted from 2010 to 2020 through electronic databases.

Results: Seven studies met the inclusion criteria. A gap exists among comparable research designs, pedagogy strategies, and outcomes specific to undergraduate nursing pathophysiology courses.

Conclusions: Findings suggest that more rigorous research designs with validated measurement instruments are needed to compare student satisfaction and outcomes after different pedagogical strategies are applied to undergraduate pathophysiology courses. Also, there is a need to elicit findings related to the retention and effectiveness of pathophysiology concepts in clinical practice.
\end{abstract}

Key Words: Undergraduate nursing education, Pathophysiology, Pedagogy, Teaching strategies

\section{INTRODUCTION}

\subsection{Background/Aim}

Pathophysiology is the science and basis of nursing practice. Pathophysiology helps students form a strong foundation for nursing practice by bridging the main pathophysiology concepts and clinical reasoning. ${ }^{11}$ The American Association of Colleges of Nursing (AACN) ${ }^{[1]}$ Essentials include pathophysiology as a required content area for baccalaureate education for professional nursing practice. The AACN ${ }^{[1]}$ indicates that an understanding of pathophysiology is needed to provide holistic, patient-centered care. In addition, the Institute of Medicine's ${ }^{[2]}$ key message from The Future of Nursing: Leading Change, Advancing Health, is that nurses must lead the change in healthcare. Nurse educators play a key role in leading a change in healthcare by means of teaching the new generation of nurses the importance of health promotion and disease prevention. ${ }^{[2]}$ Therefore, pathophysiology is required for the undergraduate nursing curriculum because nurses who understand the pathophysiological of diseases can provide higher quality patient care. ${ }^{[1,2]}$ However, understanding pathophysiology concepts are difficult for many nursing students. ${ }^{[3]}$ Furthermore, various pedagogical strategies are used in pathophysiology instruction, making it unclear to educators which type of pedagogical practice meets the challenges of teaching pathophysiology. Therefore, the aim of this systematic review was to search,

*Correspondence: Renee Colsch; Email: rcolsch@gmail.com; Address: Department of Nursing, Saint Catherine University, United States. 
extract, and synthesize research completed in the last ten years to report the current state of pedagogical strategies related to teaching pathophysiology concepts in undergraduate nursing.

\section{MeTHODS}

This review was conducted and reported in line with the Preferred Reporting Items for Systematic Reviews and MetaAnalyses (PRISMA) guidelines. ${ }^{[4]}$

\subsection{Eligibility criteria}

The inclusion criteria were pathophysiology education that included nursing students in the sample population and original research, either national or international. The search was limited to English-language and peer-reviewed articles from March 2010 to March 2020.

\subsection{Data sources}

\section{Search}

With the assistance of a professional academic librarian, the literature search included four databases: PubMed, CINAHL, MEDLINE, and Cochrane library. Within each database, the search strategy considered that index terms vary across databases. Within CINAHL, the full electronic search strategy included the following search terms: $\mathrm{MH}$ "Education, Nursing+") AND pathophysiology AND nurs* AND (education OR teaching OR instruction OR learning OR classroom OR curriculum OR flipped OR methods OR strategy OR blended OR team OR mixed OR learning OR pedagogy).

\subsection{Review methods}

\subsubsection{Study selection}

The database search strategy yielded 147 records. Websites were scanned for gray literature. Results were narrowed to 7 records based on inclusion criteria. References from these 7 records were manually searched for other relevant literature. See Figure 1 for an illustration of study selection. The Cochrane Grading of Recommendations, Assessment, Development, and Evaluation (GRADE) approach was utilized to assess studies for quality, study design, data reporting, and risk of bias. Included studies were rated as 'high' or 'low' based on the six domains of possible risk: selection, performance, detection, attrition, reporting, and other bias (see Table 1). ${ }^{[5]}$

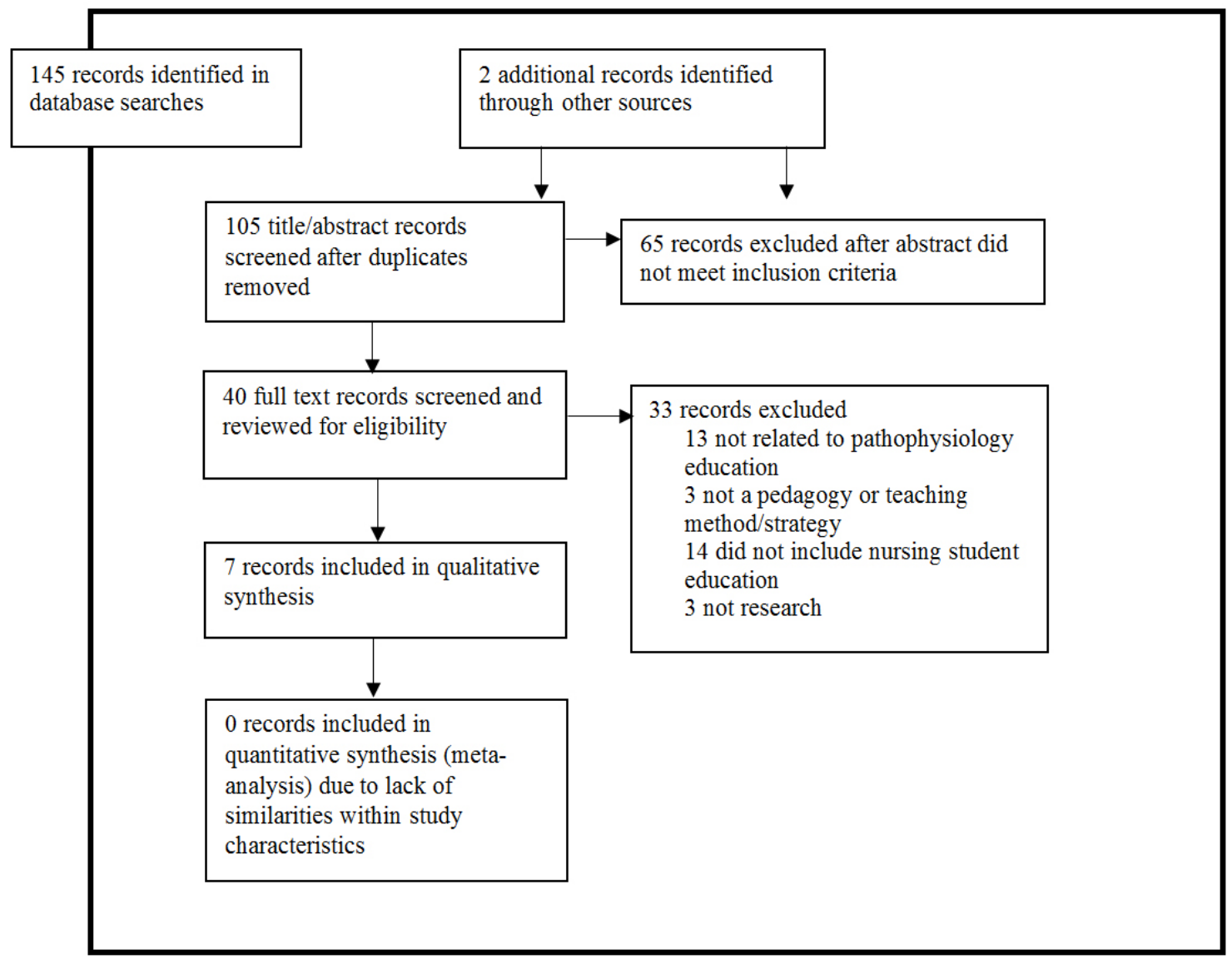

Figure 1. Flowchart for search and selection strategy 
Table 1. Summary of the state of pedagogical strategies in undergraduate nursing pathophysiology education

\begin{tabular}{|c|c|c|c|c|c|c|c|}
\hline $\begin{array}{l}\text { Author } \\
\text { Year }\end{array}$ & Design & Purpose & Sample & $\begin{array}{l}\text { Pedagogical } \\
\text { Strategies }\end{array}$ & $\begin{array}{l}\text { Measurement } \\
\text { Instrument }\end{array}$ & GRADE & Outcomes \\
\hline $\begin{array}{l}\text { Blissitt } \\
2016 \\
\text { US }\end{array}$ & $\begin{array}{l}\text { Quantitative, } \\
\text { quasi-experimental, } \\
\text { nonrandomized } \\
\text { control group, } \\
\text { pre/posttest }\end{array}$ & $\begin{array}{l}\text { Compare scores on } \\
\text { pre/posttests and } \\
\text { course satisfaction } \\
\text { between traditional and } \\
\text { blended formats in a } \\
\text { nursing } \\
\text { pathophysiology } \\
\text { course }\end{array}$ & $\begin{array}{l}\text { Nursing } \\
\text { students } \\
(N=56)\end{array}$ & $\begin{array}{l}\text { Blended } \\
\text { learning }\end{array}$ & $\begin{array}{l}\text { 18-item proctored } \\
\text { pre/posttest, and a } \\
\text { 32-item online survey. } \\
\text { The survey had } 29 \\
\text { items related to } \\
\text { educational quality } \\
\text { adopted from Marsh's } \\
\text { Student Evaluation of } \\
\text { Educational Quality } \\
\text { Questionnaire (Marsh } \\
\text { et al., 1997). }\end{array}$ & Low & $\begin{array}{l}\text { Results were } \\
\text { inconclusive. Students } \\
\text { in traditional group ( } n= \\
\text { 25) reported statistically } \\
\text { significantly higher } \\
\text { satisfaction ratings than } \\
\text { students in the blended } \\
\text { group }(n=31) \text {. }\end{array}$ \\
\hline $\begin{array}{l}\text { Branney } \\
2018 \\
\text { UK }\end{array}$ & $\begin{array}{l}\text { Mixed methods } \\
\text { observational study }\end{array}$ & $\begin{array}{l}\text { Evaluate the use of } \\
\text { team-based learning in } \\
\text { the teaching of applied } \\
\text { pathophysiology } \\
\text { to undergraduate } \\
\text { student nurses }\end{array}$ & $\begin{array}{l}\text { Year } 2 \\
\text { undergraduate } \\
\text { student } \\
\text { nurses } \\
(N=197)\end{array}$ & $\begin{array}{l}\text { Team-based } \\
\text { learning } \\
(\mathrm{TBL})\end{array}$ & $\begin{array}{l}\text { TBL-SAI, had } 33 \\
\text { items rated on a } \\
\text { five-point Likert } \\
\text { scale, reported to be } \\
\text { valid and reliable tool } \\
\text { (Mennenga, 2012). } \\
\text { Learning was assessed } \\
\text { by a two-hour unseen } \\
\text { examination paper, } \\
\text { focus group } \\
\text { discussions mirrored } \\
\text { the TBL-SAI } \\
\text { subscales }\end{array}$ & Low & $\begin{array}{l}167 \text { (85\% response rate) } \\
\text { indicated a favorable } \\
\text { experience with TBL. } \\
\text { Students reported } \\
\text { higher accountability } \\
(93 \%) \text { and satisfaction } \\
(92 \%) \text {. Exam scores on } \\
\text { TBL taught material } \\
\text { were comparable to } \\
\text { those of lecture-taught } \\
\text { material. }\end{array}$ \\
\hline $\begin{array}{l}\text { Christensen } \\
2015 \\
\text { US }\end{array}$ & Quantitative & $\begin{array}{l}\text { To develop a model } \\
\text { within Nursing } \\
\text { Practice in the Context } \\
\text { theory subject, to } \\
\text { include a bioscientist } \\
\text { lecturing to } \\
\text { complement the } \\
\text { nursing lecturer }\end{array}$ & $\begin{array}{l}\text { Undergraduate } \\
\text { Nursing } \\
\text { students } \\
(N=43)\end{array}$ & $\begin{array}{l}\text { Team teaching } \\
\text { model - bio } \\
\text { scientist and } \\
\text { nurse } \\
\text { academic }\end{array}$ & $\begin{array}{l}\text { A 15-item quantitative } \\
\text { questionnaire was } \\
\text { developed, with } \\
\text { responses scored on a } \\
\text { Likert scale (1 = } \\
\text { strongly disagree; } 5 \text { = } \\
\text { strongly agree). } \\
\text { Questionnaire items } \\
\text { related to patient care, } \\
\text { pathophysiology- } \\
\text { nursing links, and the } \\
\text { relevance of the } \\
\text { bioscientist } \\
\text { contribution. }\end{array}$ & Low & $\begin{array}{l}\text { Results support model. } \\
\text { More than } 90 \% \text { of } \\
\text { respondents agreed that } \\
\text { having a bioscientist } \\
\text { who focused on nursing } \\
\text { student needs helped to } \\
\text { increase knowledge of } \\
\text { patient conditions. }\end{array}$ \\
\hline $\begin{array}{l}\text { El Hussein } \\
2015 \\
\text { Canada }\end{array}$ & $\begin{array}{l}\text { Literature review } \\
\text { and educational } \\
\text { innovation }\end{array}$ & $\begin{array}{l}\text { Describe a teaching } \\
\text { innovation visual } \\
\text { narrative illustration } \\
\text { (VNI) and demonstrate } \\
\text { how VNIs are used to } \\
\text { teach complex } \\
\text { pathophysiology } \\
\text { concepts to nursing } \\
\text { students }\end{array}$ & NA & $\begin{array}{l}\text { Visual } \\
\text { narrative } \\
\text { illustration }\end{array}$ & NA & Low & $\begin{array}{l}\text { Use of VNI is an } \\
\text { innovative teaching } \\
\text { strategy that has } \\
\text { potential to enhance } \\
\text { other course materials } \\
\text { and bridge knowledge } \\
\text { gaps }\end{array}$ \\
\hline $\begin{array}{l}\text { Hinkle } \\
2018 \\
\text { US }\end{array}$ & $\begin{array}{l}\text { Pilot study - } \\
\text { quantitative }\end{array}$ & $\begin{array}{l}\text { Investigate the } \\
\text { feasibility and use of } \\
\text { adaptive case studies in } \\
\text { a nursing } \\
\text { pathophysiology } \\
\text { course developed } \\
\text { within the Realizeit } \\
\text { adaptive learning } \\
\text { environment. }\end{array}$ & $\begin{array}{l}\text { Students } \\
\text { enrolled in } \\
\text { undergraduate } \\
\text { nursing } \\
\text { pathophysiology } \\
(N=241)\end{array}$ & $\begin{array}{l}\text { Adaptive } \\
\text { learning } \\
\text { environment }\end{array}$ & $\begin{array}{l}\text { Realizeit captured } \\
\text { data and provided } \\
\text { information as to how } \\
\text { the students' } \\
\text { interaction with the } \\
\text { case studies impacted } \\
\text { their performance in } \\
\text { the modules }\end{array}$ & Low & $\begin{array}{l}\text { Preliminary evidence } \\
\text { supports the use of } \\
\text { adaptive case studies in } \\
\text { nursing education }\end{array}$ \\
\hline $\begin{array}{l}\text { Lewis } \\
2017 \\
\text { US }\end{array}$ & Quantitative & $\begin{array}{l}\text { Determine if students } \\
\text { identified key content } \\
\text { information to use } \\
\text { in their haiku and to } \\
\text { determine if students } \\
\text { were engaged the } \\
\text { creation of the haiku }\end{array}$ & $\begin{array}{l}\text { Undergraduate } \\
\text { pathophysiology } \\
\text { courses }(N=91)\end{array}$ & $\begin{array}{l}\text { Active } \\
\text { learning - } \\
\text { haiku }\end{array}$ & $\begin{array}{l}\text { Survey of } 5 \text { questions } \\
\text { used a four-point } \\
\text { Likert scale }\end{array}$ & Low & $\begin{array}{l}16 \text { accelerated students } \\
\text { completed the survey } \\
\text { and } 63 \text { were traditional } \\
\text { students. Students } \\
\text { found haiku exercise } \\
\text { engaging, and that it } \\
\text { promoted active } \\
\text { learning within a group. }\end{array}$ \\
\hline $\begin{array}{l}\text { Marques } \\
2016 \\
\text { US }\end{array}$ & Quantitative & $\begin{array}{l}\text { A problem-based } \\
\text { hybrid } \\
\text { pathophysiology } \\
\text { course was designed to } \\
\text { enhance students' } \\
\text { comprehension of } \\
\text { material and } \\
\text { application in the } \\
\text { clinical setting }\end{array}$ & $\begin{array}{l}\text { Second-year } \\
\text { nursing degree } \\
\text { students } \\
(N=964)\end{array}$ & $\begin{array}{l}\text { Problem-based } \\
\text { hybrid } \\
\text { learning } \\
\text { on-line } \\
\text { platform was } \\
\text { Moodle }^{\odot}\end{array}$ & $\begin{array}{l}\text { Case of the week } \\
\text { indicators and person- } \\
\text { al satisfaction and } \\
\text { learning outcomes } \\
\text { (assessed through an } \\
\text { online questionnaire) }\end{array}$ & Low & $\begin{array}{l}\text { Success of this method } \\
\text { by students' approvals: } \\
\text { l,126 ( } 4.6 \%) \text { students in } \\
2012 \text { to } 2013(n=303) \text {. } \\
1,132(39.3 \%) \text { students } \\
\text { in } 2013 \text { to } 2014 \text { ( } n= \\
336) \text {. } \\
1,144(44.3 \%) \text { students } \\
\text { in } 2014 \text { to } 2015 \text { ( } n= \\
325) \text {. }\end{array}$ \\
\hline
\end{tabular}




\subsubsection{Data collection process}

Data extraction was completed for the 7 identified articles. The lead author extracted the following data: Author/year, design, purpose, sample, pedagogy intervention, measurement instrument, GRADE, and outcomes. All authors then checked the data, and a consensus was reached. The quantitative synthesis was not completed due to the lack of similarities within study characteristics.

\section{RESUlts}

This review indicates that gaps exist among comparable research designs, pedagogy strategies, and outcomes specific to undergraduate nursing pathophysiology courses. Also, a gap exists in findings related to the retention and effectiveness of pathophysiology concepts in clinical practice.

\subsection{Designs}

Five studies used a quantitative design, one study was mixed methods, and one study was a literature review. Four quantitative and the one mixed methods study used satisfaction surveys within one group of nursing students. ${ }^{[6-11]}$ Two of these five surveys were adopted from valid and reliable measurement instruments. ${ }^{[6,7]}$ One quantitative study $(\mathrm{N}=56)$ used a pretest-posttest design with nursing students in traditional $(\mathrm{n}=25)$ and blended $(\mathrm{n}=31)$ groups. ${ }^{[6]}$ The one mixed method qualitative design used focus group discussions. ${ }^{[7]}$ The literature review described visual narrative as a teaching innovation for teaching pathophysiology concepts. ${ }^{[12]}$

\subsection{Sample and setting}

Sample sizes for these six studies, including the mixed method study but minus the literature review, ranged from 56 to 964 , with a median of $510 .^{[6-12]}$ Each study included prelicensure nursing students enrolled in undergraduate pathophysiology courses. ${ }^{[6-12]}$ Also, each study was conducted in an academic setting with four studies in the United States, one study in the United Kingdom, and one study in Canada. ${ }^{[6-12]}$ All studies were conducted in the academic setting by nursing faculty. ${ }^{[6-12]}$ One study included a bioscientist faculty. ${ }^{[8]}$

\subsection{Pedagogical strategies}

Table 1 illustrates the pedagogical models used in pathophysiology instruction. All seven studies took an active learning strategy under the Constructivist theory. ${ }^{[6-12]}$ Specific pedagogical strategies included: blended $(\mathrm{N}=56),{ }^{[6]}$ team-based $(\mathrm{N}=253),{ }^{[7,8]}$ visual narrative illustration, ${ }^{[12]}$ adaptive learning environment $(\mathrm{N}=241),{ }^{[9]}$ active learning haiku $(\mathrm{N}=$ 91) ${ }^{[10]}$ and problem-based hybrid $(\mathrm{N}=964) .{ }^{[11]}$

\subsection{Measurement instruments}

Two studies indicated using a validated tool and provided reference to a previous publication, which indicates psychometric tool testing. ${ }^{[6,7]}$ Table 1 provides the names of the validated instruments. One of these two studies also indicated using examination data and qualitative interviews. ${ }^{[7]}$ The four other studies indicated using survey questionnaires, grades, and computer program generated aggravated data. ${ }^{[8-11]}$ One study was a review of the literature, and no report was provided on specific study tools. ${ }^{[12]}$

\subsection{Outcome}

Outcomes for the six studies were generally all positive. ${ }^{[6-12]}$ Outcomes primarily evaluated student satisfaction, engagement, and success measured by surveys, course, or assignment grades. ${ }^{[6-12]}$

\section{Discussion}

Only two studies conducted a rigorous research design with validated measurement tools. ${ }^{[6,7]}$ This lack of rigorous research may be the direct result of the limited focus on pedagogical design in pathophysiology courses. Current pathophysiology courses are often taught using traditional pedagogy models, ${ }^{[13]}$ despite the criticism of the lack of teaching strategy effectiveness. ${ }^{[14,15]}$ The use of traditional pedagogy models maybe because of how the depth and breadth of pathophysiology concepts make it well suited for traditional pedagogical delivery. Although educators recognize that teaching pathophysiology concepts with active learning pedagogies is substantial to student learning, the lack of reported studies on pedagogical practice for pathophysiology instruction makes it challenging to implement pedagogies other than the traditional method. ${ }^{[1,2,4,13]}$ Therefore, this lack of reported studies comparing different pedagogical strategies increases educators' struggle to identify the most effective pedagogy for student success and strategies in their current traditional pathophysiology courses. ${ }^{[6]}$ The current literature reports on outcomes of six different pedagogy interventions within undergraduate pathophysiology nursing courses: blended, team-based, visual narrative illustration, adaptive learning environment, active learning haiku, and problembased hybrid. ${ }^{[6-12]}$ However, due to the paucity of research specific to pedagogy interventions and the lack of similar research design in undergraduate pathophysiology courses, a comparison of study results on pedagogical effectiveness is limited.

Gaps in the literature remain, and further research is needed to support the use of non-traditional pedagogy interventions. El Hussein, Salyers, and Osuji ${ }^{[12]}$ literature review highlighted that most of the previous literature on strategies to 
teach pathophysiology recommended the need for educators to use a variety of teaching strategies to meet students' different learning styles. Similarly, this review highlighted that although multiple teaching strategies have been used, the traditional lecture format remains the most common method for nursing pathophysiology delivery. ${ }^{[12]}$ Only two studies compared undergraduate nursing students' pathophysiology scores and satisfaction with another pedagogical strategy to the traditional method. ${ }^{[6,7]}$ Also, Blissitt ${ }^{[6]}$ recommended further research to support the use of blended learning with a focus on identifying teaching strategies that foster student satisfaction and success in nursing pathophysiology courses. Findings from Branney and Priego-Hernández ${ }^{[7]}$ also recommend that future studies are needed to compare outcomes of a team-based learning model to other teaching strategies as well as longitudinal studies to examine knowledge retention in clinical practice. The lack of reported comparable pedagogical studies warrants the need for studies that compare outcomes after the use of different pedagogical strategies as applied to undergraduate nursing pathophysiology courses.

Another area needing further research is the retention and effectiveness of applying pathophysiology concepts in clinical practice. Christensen et al. ${ }^{[8]}$ study indicated that their teamteaching approach effectively enhanced students' ability to link pathophysiology concepts to nursing practice. Also, Christensen et al. ${ }^{[8]}$ stated, "improved understanding of the knowledge and application of pathophysiology will better inform clinical decisions, and ultimately improve quality of patient care" (p. 3741). Hinkle and Moskal ${ }^{[9]}$ indicated that their pilot study supports an adaptive learning environment in nursing education. However, future studies need to be done to examine the impact of students' engagement with adaptive case studies on knowledge and outcomes. ${ }^{[9]}$ Similarly, Lewis ${ }^{[10]}$ found that a Haiku active learning approach was effective in promoting active learning among undergraduate pathophysiology students. However, educators need to determine the best place to use haiku in their courses. None of these studies measured the effectiveness of applying pathophysiology concepts to nursing practice. Furthermore, these

\section{REFERENCES}

[1] AACN: The Essentials of Baccalaureate Education for Professional Nursing Practice. Fiscal year 2008. [Internet]. American Association of Colleges of Nursing. c2008 [cited 2020 Feb] Available from: http://www.aacnnursing.org/portals/42/pub lications/baccessentials08.pdf

[2] IOM: The Future of Nursing: Leading Change, Advancing Health. [Internet]. Institute of Medicine (US) Committee on the Robert Wood studies did not compare outcomes from different pedagogical strategies utilized in undergraduate pathophysiology courses.

In terms of what pedagogical strategies these studies recommend for undergraduate nursing pathophysiology courses, there needs to be research studies that use validated measurement instruments to specifically evaluate pedagogical strategies utilized in undergraduate nursing pathophysiology courses. Only one study was longitudinal over three years, ${ }^{[11]}$ and two studies used a validated survey. ${ }^{[6,7]}$ The lack of reported comparable pedagogical studies specific to nursing pathophysiology and the lack of validated measurement instruments do not allow educators to determine the best strategy to apply in nursing pathophysiology courses. Future research should include these aspects to better discern the implications and generalizability of applying such strategies.

\section{Conclusions}

The aim of this systematic literature review was to search, extract, and synthesize research completed in the last ten years to report the current state of pedagogical strategies related to teaching pathophysiology concepts in undergraduate nursing. This review indicates that gaps exist among comparable research designs, pedagogy strategies, and outcomes specific to undergraduate nursing pathophysiology courses. Also, a gap exists in findings related to the retention and effectiveness of pathophysiology concepts in clinical practice. Therefore, further research is needed to compare student satisfaction and outcomes after different pedagogical strategies are applied to undergraduate pathophysiology courses. Further research is needed on the retention and effectiveness of applying pathophysiology concepts in clinical practice. Studies that specifically evaluate pedagogical strategies as applied in undergraduate nursing pathophysiology courses will provide evidence at the higher level of analysis and evaluation of educational style, which will help educators decide the best strategy to apply in their course.

\section{CONFLicts OF INTEREST Disclosure}

The authors declare that there is no conflict of interest.
Johnson Foundation Initiative on the Future of Nursing, at the Institute of Medicine. c2011 [cited 2020 Feb] National Academies Press (US). Available from: https://pubmed.ncbi.nlm.nih.gov/24 983041/

[3] McVicar A, Andrew S, Kemble R. The 'bioscience problem' for nursing students: an integrative review of published evaluations of Year 1 bioscience, and proposed directions for curriculum development, Nurse Education Today. 2015; 35(3): 500-509. PMid:25534183 
https://doi.org/10.1016/j.nedt.2014.11.003

[4] Moher D, Shamseer L, Clarke M, et al. Preferred reporting items for systematic review and meta-analysis protocols (PRISMA-P) 2015 statement. Systematic Reviews. 2015; 4(1): 1. PMid:25554246 https ://doi.org/10.1186/2046-4053-4-1

[5] Schünemann H, Brożek J, Guyatt G, et al. GRADE Working Group. GRADE Handbook; Handbook for grading the quality of evidence and the strength of recommendations using the GRADE approach. [Internet]. 2013 [cited 2020 Feb]. Available from: https://gdt. gradepro.org/app/handbook/handbook.html

[6] Blissitt AM. Blended Learning Versus Traditional Lecture in Introductory Nursing Pathophysiology Courses. The Journal of Nursing Education. 2016; 55(4): 227-230. PMid:27023894 https: //doi.org/10.3928/01484834-20160316-09

[7] Branney J, Priego-Hernández J. A mixed methods evaluation of team-based learning for applied pathophysiology in undergraduate nursing education. Nurse Education Today. 2018; 61: 127-133. PMid:29197687 https ://doi.org/10.1016/j.nedt.2017.11 .014

[8] Christensen M, Craft JA, Wirihana L, et al. Pathophysiology team teaching: Bioscientist contribution to knowledge integration in a nursing subject. Journal of Clinical Nursing. 2015; 24(23-24): 3739-3741. PMid:26334041 https://doi.org/10.1111/jocn. 12959

[9] Hinkle JF, Moskal P. A preliminary examination of adaptive case studies in nursing pathophysiology. Current Issues in Emerging eLearning.
2018; 5(1): 3. https://scholarworks.umb.edu/ciee/vol5/i ss $1 / 3$

[10] Lewis HA. Haiku to enhance student learning: Experiences from a pathophysiology classroom. Nurse Education Today. 2018; 60: 98100. PMid:29073510 https://doi.org/10.1016/j.nedt. 201 7.09 .018

[11] Marques PA, Correia NC. Nursing Education Based on "Hybrid" Problem-Based Learning: The Impact of PBL-Based Clinical Cases on a Pathophysiology Course. The Journal of Nursing Education. 2017; 56(1): 60. PMid:28118478 https://doi.org/10.3928/01 484834-20161219-12

[12] El Hussein MT, Salyers V, Osuji J. Use of Visual Narrative Illustrations to Teach Pathophysiology Concepts to Nursing Students. The Journal of Nursing Education. 2016; 55(2): 109-112. PMid:26814823 https ://doi.org/10.3928/01484834-20160114-10

[13] Van Horn ER, Hyde YM, Tesh AS, et al. Teaching pathophysiology: Strategies to enliven the traditional lecture. Nurse Educator. 2014; 39: 34-37. PMid:24300257 https ://doi.org/10.1097/01. NNE .0000437364 .19090 . be

[14] Herrman JW. Keeping their attention: innovative strategies for nursing education. Journal of Continuing Education in Nursing. 2011; 42(10): 449-456. PMid:21598848 https://doi.org/10.3928/ 00220124-20110516-05

[15] Isseks M. How PowerPoint is killing education. Educational Leadership. 2011; 68(5): 74-76. 